\title{
Front Matter: Volume 9790
}

, "Front Matter: Volume 9790," Proc. SPIE 9790, Medical Imaging 2016: Ultrasonic Imaging and Tomography, 979001 (2 June 2016); doi: $10.1117 / 12.2240428$

SPIE. Event: SPIE Medical Imaging, 2016, San Diego, California, United States 


\title{
PROGRESS IN BIOMEDICAL OPTICS AND IMAGING
}

\section{Medical Imaging 2016}

\section{Ultrasonic Imaging and Tomography}

\author{
Neb Duric \\ Brecht Heyde \\ Editors
}

\section{8-29 February 2016}

San Diego, California, United States

Sponsored by

SPIE

\section{Cosponsored by}

Modus Medical Devices Inc. (Canada) • Bruker (United States) • Poco Graphite (United States) • imXPAD (France)

\section{Cooperating Organizations}

AAPM-American Association of Physicists in Medicine (United States) - APS—American Physiological Society (United States) - IFCARS - International Foundation for Computer Assisted Radiology and Surgery (Germany) - Medical Image Perception Society (United States) • Radiological Society of North America (United States) - Society for Imaging Informatics in Medicine (United States) • World Molecular Imaging Society • The DICOM Standards Committee

Published by

SPIE 
The papers in this volume were part of the technical conference cited on the cover and title page. Papers were selected and subject to review by the editors and conference program committee. Some conference presentations may not be available for publication. Additional papers and presentation recordings may be available online in the SPIE Digital Library at SPIEDigitallibrary.org.

The papers reflect the work and thoughts of the authors and are published herein as submitted. The publisher is not responsible for the validity of the information or for any outcomes resulting from reliance thereon.

Please use the following format to cite material from these proceedings:

Author(s), "Title of Paper," in Medical Imaging 2016: Ultrasonic Imaging and Tomography, edited by Neb Duric, Brecht Heyde, Proceedings of SPIE Vol. 9790 (SPIE, Bellingham, WA, 2016) Six-digit Article CID Number.

ISSN: 1605-7422

ISSN: 2410-9045 (electronic)

ISBN: 9781510600256

Published by

SPIE

P.O. Box 10, Bellingham, Washington 98227-0010 USA

Telephone +1 3606763290 (Pacific Time) · Fax +1 3606471445

SPIE.org

Copyright (C) 2016, Society of Photo-Optical Instrumentation Engineers.

Copying of material in this book for internal or personal use, or for the internal or personal use of specific clients, beyond the fair use provisions granted by the U.S. Copyright Law is authorized by SPIE subject to payment of copying fees. The Transactional Reporting Service base fee for this volume is $\$ 18.00$ per article (or portion thereof), which should be paid directly to the Copyright Clearance Center (CCC), 222 Rosewood Drive, Danvers, MA 01923. Payment may also be made electronically through CCC Online at copyright.com. Other copying for republication, resale, advertising or promotion, or any form of systematic or multiple reproduction of any material in this book is prohibited except with permission in writing from the publisher. The CCC fee code is $1605-7422 / 16 / \$ 18.00$.

Printed in the United States of America.

Publication of record for individual papers is online in the SPIE Digital Library.

\section{SPIE. DIGITAL}

SPIEDigitalLibrary.org

Paper Numbering: Proceedings of SPIE follow an e-First publication model. A unique citation identifier (CID) number is assigned to each article at the time of publication. Utilization of CIDs allows articles to be fully citable as soon as they are published online, and connects the same identifier to all online and print versions of the publication. SPIE uses a six-digit CID article numbering system structured as follows:

- The first four digits correspond to the SPIE volume number.

- The last two digits indicate publication order within the volume using a Base 36 numbering

system employing both numerals and letters. These two-number sets start with 00, 01, 02, 03, 04, 05, 06, 07, 08, 09, OA, OB ... 0Z, followed by 10-1Z, 20-2Z, etc. The CID Number appears on each page of the manuscript. 


\title{
Contents
}

\author{
vii Authors \\ xi Conference Committee \\ xiii 2016 Medical Imaging Award Recipients
}

\section{SESSION 1 MOTION AND DEFORMATION IMAGING}

979002 Perfusion imaging with non-contrast ultrasound [9790-1]

979003 Blood flow velocity in the popliteal vein using transverse oscillation ultrasound [9790-2]

979004 High frame rate synthetic aperture vector flow imaging for transthoracic echocardiography [9790-3]

979005 3D vector flow using a row-column addressed CMUT array [9790-4]

979006 Fast myocardial strain estimation from 3D ultrasound through elastic image registration with analytic regularization [9790-5]

\section{SESSION 2 ULTRASOUND TOMOGRAPHY AND RECONSTRUCTION}

979007 Breast fumour visualization using 3D quantitative ultrasound methods [9790-6]

979008 Spatial smoothing coherence factor for ultrasound computed tomography [9790-7]

979009 Analysis of patient movement during 3D USCT data acquisition [9790-8]

9790 OA 3D ultrasound computer tomography: update from a clinical study [9790-9]

$9790 \mathrm{OB} \quad$ Ultrasound breast imaging using frequency domain reverse time migration [9790-10]

9790 OC Frequency-domain ultrasound waveform tomography breast attenuation imaging [9790-11]

\section{SESSION 3 ULTRASOUND IMAGE ANALYSIS AND TISSUE CHARACTERIZATION}

9790 OD Automatic left-atrial segmentation from cardiac 3D ultrasound: a dual-chamber model-based approach [9790-12]

9790 OE Automatic short axis orientation of the left ventricle in 3D ultrasound recordings [9790-13]

9790 OF Robust spatio-temporal registration of 4D cardiac ultrasound sequences [9790-14] 
9790 OG A new approach to ultrasonic elasticity imaging [9790-15]

$9790 \mathrm{OH} \quad$ Experimental characterization, comparison and image quality assessment of two ultrasound contrast agents: Optison and Definity [9790-16]

SESSION 4 ULTRASOUND IMAGE GUIDANCE: JOINT SESSION WITH CONFERENCES 9786 AND 9790

9790 Ol Development of 3D ultrasound needle guidance for high-dose-rate interstitial brachytherapy of gynaecological cancers [9790-17]

9790 0J Preliminary investigation of an ultrasound method for estimating pressure changes in deep-positioned vessels [9790-18]

9790 OK Novel automatic detection of pleura and B-lines (comet-tail artifacts) on in-vivo lung ultrasound scans [9790-19]

SESSION 5 NOVEL IMAGING STRATEGIES AND SIGNAL PROCESSING

9790 OL SUb-mSV breast XACT scanner: concept and design [9790-20]

9790 OM An evolutionary Bayesian search scheme for ultrasound modulated optical tomography [9790-21]

$97900 \mathrm{~N} \quad$ Monte Carlo investigation of the dosimetric effect of the Autoscan ultrasound probe for guidance in radiotherapy [9790-22]

$979000 \quad$ Ultrasound perfusion signal processing for fumor detection [9790-23]

9790 OP Frequency-shift low-pass filtering and least mean square adaptive filtering for ultrasound imaging [9790-24]

\section{SESSION 6 KEYNOTE AND NEW APPLICATIONS OF ULTRASOUND IN MEDICINE AND BIOLOGY}

$97900 Q \quad$ Enhanced ultrasound for advanced diagnostics, ultrasound tomography for volume limb imaging and prosthetic fitting (Keynote Paper) [9790-25]

9790 OR 3D optical imagery for motion compensation in a limb ultrasound system [9790-26]

9790 OS Quantitative head ultrasound measurements to determine thresholds for preterm neonates requiring interventional therapies following intraventricular hemorrhage [9790-27]

9790 OT Development and evaluation of a novel VEGFR2-targeted nanoscale ultrasound contrast agents [9790-28]

\section{SESSION 7 TRANSDUCERS AND BEAMFORMING}

9790 OU A pseudo non-linear method for fast simulations of ultrasonic reverberation [9790-29]

iv 
9790 OV A beamforming method for plane wave Doppler imaging of high flow velocities [9790-30]

9790 0W Detection of and compensation for blocked elements using large coherent apertures: ex vivo studies [9790-31]

$97900 X$ Real-time 3D image reconstruction of a $24 \times 24$ row-column addressing array: from raw data to image [9790-32]

9790 OY Volumetric synthetic aperture imaging with a piezoelectric 2D row-column probe [9790-33]

$97900 Z$ Optimization of synthetic aperture image quality [9790-34]

979010 Analog gradient beamformer for a wireless ultrasound scanner [9790-35]

\section{POSTER SESSION}

979011 Automated 3D ultrasound image segmentation for assistant diagnosis of breast cancer [9790-36]

979012 Development of estimation system of knee extension strength using image features in ultrasound images of rectus femoris [9790-37]

979013 Precise reconstruction of fast moving cardiac valve in high frame rate synthetic transmit aperture ultrasound imaging [9790-38]

979014 Effect of echo artifacts on characterization of pulsatile tissues in neonatal cranial ultrasonic movies [9790-39]

979015 Determining cardiac fiber orientation using FSL and registered ultrasound/DTI volumes [9790-40]

979016 Ultrasound transmission attenuation tomography using energy-scaled amplitude ratios [9790-41]

979017 Image reconstruction for robot assisted ultrasound tomography [9790-42]

979018 Phase aberration correction by multi-stencils fast marching method using sound speed image in ultrasound computed tomography [9790-43]

979019 Using ultrasound tomography to identify the distributions of density throughout the breast [9790-44]

$97901 \mathrm{~A} \quad$ Automated kidney morphology measurements from ultrasound images using texture and edge analysis [9790-45]

9790 1B Automated kidney detection for 3D ultrasound using scan line searching [9790-46]

9790 1C US-Cut: interactive algorithm for rapid detection and segmentation of liver tumors in ultrasound acquisitions [9790-47]

9790 1D Delimitation of the lung region with distributed ultrasound transducers [9790-48] 
$97901 \mathrm{E} \quad$ Rotation elastogram: a novel method to visualize local rigid body rotation under quasi-static compression [9790-49]

$97901 \mathrm{~F} \quad$ Dynamic programming on a tree for ultrasound elastography [9790-50]

9790 1G Image-based temporal alignment of echocardiographic sequences [9790-51]

$9790 \mathrm{lH} \quad$ Comparison of ultrasound B-mode, strain imaging, acoustic radiation force impulse displacement and shear wave velocity imaging using real time clinical breast images [9790-53]

979011 Differential diagnosis of thyroid nodules with virtual touch tissue imaging of ARFI elastography [9790-54]

979010 Frequency-space prediction filtering for acoustic clutter and random noise attenuation in ultrasound imaging [9790-60]

$97901 \mathrm{P} \quad$ Towards predictive diagnosis and management of rotator cuff disease: using curvelet transform for edge detection and segmentation of tissue [9790-61]

$97901 Q \quad$ Classification of motor intent in transradial amputees using sonomyography and spatio-temporal image analysis [9790-62]

9790 IR Single element ultrasonic imaging of limb geometry: an in-vivo study with comparison to MRI [9790-63]

$97901 \mathrm{~T}$ Observations of liver cancer cells in scanning probe acoustic microscope: a preliminary study [9790-65]

9790 IU A preliminary evaluation work on a 3D ultrasound imaging system for 2D array transducer [9790-66]

$97901 \mathrm{~V} \quad$ A new post-phase rotation based dynamic receive beamforming architecture for smartphone-based wireless ultrasound imaging [9790-67]

9790 IW High-resolution synthetic aperture ultrasound imaging with minimum variance beamforming and spiking deconvolution [9790-68]

9790 1X In vivo visualization of robotically implemented synthetic tracked aperture ultrasound (STRATUS) imaging system using curvilinear array [9790-69]

9790 IY Large-pitch steerable synthetic transmit aperture imaging (LPSSTA) [9790-70]

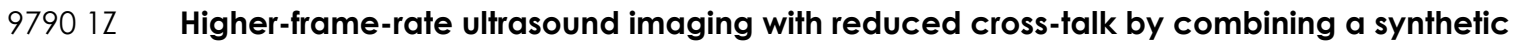
aperture and spatial coded excitation [9790-71] 


\section{Authors}

Numbers in the index correspond to the last two digits of the six-digit citation identifier (CID) article numbering system used in Proceedings of SPIE. The first four digits reflect the volume number. Base 36 numbering is employed for the last two digits and indicates the order of articles within the volume. Numbers start with 00, 01, 02, 03, 04, 05, 06, 07, 08, 09, 0A, OB...0Z, followed by 10-1Z, 20-2Z, etc.

Aalamifar, Fereshteh, 17, 1X

Abbey, Craig K., 00

Aklaghi, Nima, 1Q

Alessandrini, Martino, 06

Almeida, Nuno, OD

Annangi, Pavan, 1A

Anthony, Brian W., OQ, OR, IR

Azuma, Takashi, 18

Baekgaard, Niels, 03

Bagge, Jan Peter, 05, 10

Baker, Clayton A., $1 Q$

Bamber, Jeffrey, ON

Bechsgaard, Thor, 03, 04

Beers, Christopher, 05, OY

Bersvendsen, Jørn, OF, 1G

Boctor, Emad M., 17, 1X

Boily, Mathieu, $1 \mathrm{~F}$

Boone, Michael, OC

Bottenus, Nick, OW

Bouzari, Hamed, OY

Brandt, Andreas Hjelm, 03

Byram, Brett C., 02, OU

C., Sowmiya, $1 \mathrm{E}$

Cardona Cárdenas, Diego Armando, ID

Carson, Paul L., 11

Chakraborty, Bidisha, 06

Chee, Adrian J. Y., 0J

Chen, Jian, OL

Chen, Ting, 16

Chen, Xiaohui, $1 \mathrm{~T}$

Chen, Xiaojun, 1C

Christiansen, Thomas Lehrmann, 05, OY

Claus, Piet, OE

Czarnota, Gregory J., 07

Dahl, Jeremy, OW

Danudibroto, Adriyana, OF, IG

Day, Steven W., $\mathrm{OH}$

de Ribaupierre, Sandrine, OS

D'hooge, Jan, 06, OD, OE, IG

Di lanni, Tommaso, 10

Ding, Mingyue, 08, OP, OT, OX, 11, 1T, $1 \mathrm{U}$

Dokter, Mark, 1C

Dormer, James, 15

D'Souza, D., ol

Du, Sidan, 11

Dumont, Douglas M., 02

Duric, Neb, OB, OC, 19

Edvardsen, Thor, $\mathrm{OE}$

Egger, Jan, 1C
Engholm, Mathias, 05, OY

Engvall, Jan, OE

Estépar, Raúl San José, OF

Ewertsen, Caroline, OK

Fang, Xiaoyue, $1 \mathrm{~T}$

Fatemi, Mostafa, $0 \mathrm{G}$

Fei, Baowei, 15

Feigin, Micha, OR

Fenster, Aaron, Ol, OS

Fincke, Jonathan R., IR

Foley, Mark J., ON

Fujita, Hiroshi, 12

Fukuoka, Daisuke, 12

Fukuzawa, Masayuki, 14

Furvie, Sérgio Shiguemi, 1D

Gangeh, Mehrdad J., 07

Gemmeke, H., 09, 0A

Gérard, Olivier, OD, $1 G$

Ghaboussi, Jamshid, OG

Gierach, Gretchen L., 19

Gilroy, Stephen, ON

Gu, Peng, 11

Guo, Hua, $1 T$

Hadizad, Farnoosh, 07

Hajdok, G., Ol

Hann, Alexander, 1C

Hansen, Kristoffer Lindskov, 03, OK

Hara, Takeshi, 12

Hariharan, Harishwaran, 1Q

Harris, Emma, ON

He, Xiaoling, OT

Heeren, Laurens, OE

Hemmsen, Martin Christian, OK, 0Z, 10

Henrich, J., OA

Herr, Hugh M., OR

Heyde, Brecht, 06, OE

Ho, Chung Kit, OJ

Hoerig, Cameron, OG

Hofmann, Michael, 1C

Holbek, Simon, 03, 05

Hopp, T., 09, 0A

Huang, Lianjie, 16, 10, 1W

Hughes, Amy C., $\mathrm{OH}$

Ikeda, Teiichiro, 13, 12

Imoto, Haruka, 18

Insana, Michael F., 0G, 0O

Ishihara, Chizue, 13, 12

Jakovljevic, Marko, oW

Jensen, Henrik, 10 
Jensen, Jonas, $\mathrm{OZ}$

Jensen, Jørgen Arendt, 03, 04, 05, 0J, OK, OY, 0Z, 10

Jiang, Rong, 15

Kaiser, C., OA

Kang, Jeeun, IV

Kim, Min, $1 \mathrm{~V}$

Kim, MinWoo, 00

Kishimoto, Jessica, OS

Kitsunezuka, Yoshiki, 14

Knaudt, J., OA

Kolios, Michael C., IY

Kosecka, Jana, 1Q

Kothawala, Ali Arshad, 1E

Kretzek, E., 09, 0A

Kumar, Shalki, OW

Kuo, Lily, OW

Kwartowitz, David M., IP

Lacefield, James C., OV

Lanning, Justin, $1 \mathrm{~A}$

Lee, David S. C., OS

Lee, Gunho, $1 \mathrm{~V}$

Lee, Won-Mean, 11

Lei, Anders, 05, OY

Leung, E., Ol

Li, Chunfang, OT

Li, Chunyu, OP, OX, $1 \mathrm{U}$

Li, Cuiping, OC

Li, Tao, 11

Li, XU, OX, $1 \mathrm{U}$

Li, Ying, $1 Y$

Li, Yiyong, 11

Lin, Hongxiang, 18

Linte, Cristian A., $\mathrm{OH}$

Littrup, Peter, 19

Liv, Hong, OL

Liu, Simon, 07

Lönn, Lars, 03

Lou, Cuijuan, 08

Machireddy, Ramasubba Reddy, $1 \mathrm{H}$

Manickam, Kavitha, $1 \mathrm{H}$

Mansour, Omar, OV

Martineau, Paul A., IF

Martyn, Michael, ON

Masuzawa, Hiroshi, 13, 1 Z

Matsumoto, Yoichiro, 18

Mi, Yongwei, 11

Mirea, Oana, $1 G$

Mireault, $\mathrm{Al}, \mathrm{OR}$

Moesner, Lars Nordahl, 05

Møller Sørensen, Hasse, OK

Montgomery, Katelyn, OC

Moshavegh, Ramin, OK, $\mathrm{OZ}$

Murakami, Hiroki, 12

Muramatsu, Chisako, 12

Nadolny, Anne, 1B

Nielsen, Michael Bachmann, 03, 04, OK

Nikolov, Svetoslav Ivanov, OY

Noll, Matthias, 1B

O'Shea, Tuathan, ON
Olesen, Jacob Bjerring, 0J

Orderud, Fredrik, OD

Pai Raikar, Vipul, IP

Papachristidis, Alexandros, OE

Park, Minsuk, IV

Pedrosa, João, OE

Poepping, Tamie L., OV

Pratt, R. G., OB

Qin, Xulei, 15

Qu, Xiaolei, 18

Raghavan, Bagyam, $1 \mathrm{H}$

Raheem, Abdul, 07

Rahmim, Arman, 17

Ranger, Bryan J., OR

Rangwala, Huzefa, $1 Q$

Raskar, Ramesh, OR

Ravishankar, Hariharan, IA

Ren, Liqiang, $\mathrm{OL}$

Rivaz, Hassan, IF

Rodgers, J., 0 l

Romano, Walter, OS

Roubidoux, Marilyn A., 11

Roy, Debasish, OM

Roy, Olivier, OB, OC

Ruiter, N. V., 09, 0A

Sak, Mark, 19

Sakuma, Ichiro, 18

Salehi, Fateme, OS

Samant, Pratik, OL

Samset, Eigil, OD, OF, IG

Sandhu, Gursharan Yash Singh, OC

Sarvari, Sebastian I., OD

Schmalstieg, Dieter, 1C

Schwarz, Karl Q., OH

Shams, Roozbeh, $1 \mathrm{~F}$

Shen, Ming, 15

Sherman, Mark E., 19

Shin, Junseob, 16, 10, 1W

Shu, Jasmine, OU

Sikdar, Siddhartha, $1 Q$

Song, Junjie, OX, IU

Song, Tai-Kyong, $1 \mathrm{~V}$

Strandberg, Charlotte, 03

Stuart, Matthias Bo, 04, 05, OY, OZ

Suzuki, Mayumi, 13

Tabata, Yuki, 14

Tadayyon, Hadi, 07

Takagi, Shu, 18

Takahashi, Kazuki, 14

Takano, Shinta, 13

Tamano, Satoshi, 18

Tang, Shanshan, OL

Terabayashi, Nobuo, 12

Tessier, D., Ol

Thittai, Arun K., 1E

Thomsen, Erik Vilain, 05, OY

Tierney, Jaime E., 02

Toews, Matthew, OF

Traberg, Marie Sand, OJ

Trahey, Gregg, OW 
Tukalo, A., OA

Umemura, Shin-Ichiro, 18

Urheim, Stig, OF

Vardi, Nitsan, 10

Vasu, Ram Mohan, OM

Venugopal, Mamatha, OM

Villagómez-Hoyos, Carlos Armando, 04, OJ, $0 Z$

Voglreiter, Philip, 1C

Wagner, Mary B., 15

Wang, Shanshan, OP

Wang, Silun, 15

Wang, Xueding, 11

Wang, Yuxin, 11

Washburn, Michael, 1A

Watanabe, Tsuneo, 12

Wells, William M., III, OF

Wesarg, Stefan, 1B

West, Erik, OC

Xi, Qing, $1 T$

Xiang, Liangzhong, $\mathrm{OL}$

$\mathrm{XU}$, Mengling, 08

$X u, Y$ Yun, $1 Y$

Yang, Jiali, OX, $1 \mathrm{U}$

Yiu, Billy Y.S., OJ

Yu, Alfred C. H., OJ

Yu, Hougiang, OT

Yuan, Jie, 11

Yuchi, Ming, 08, OP, 0X, $1 \mathrm{U}$

Zamorano, Jose, $\mathrm{OE}$

Zapf, M., 09, 0A

Zhang, Haichong K., 17, $1 \mathrm{X}$

Zhang, Ji, 11

Zhang, Ning, $1 T$

Zhang, Xiang, OR, IR

Zhang, Xiaodong, 15

Zhong, Xiaoli, OX, IU

Zhou, Pei, 11

Zhou, Qibing, OT

Zoller, Wolfram G., 1C

Zuberi, M. A. H., OB

Proc. of SPIE Vol. $9790979001-9$ 
Proc. of SPIE Vol. $9790979001-10$

Downloaded From: https://www.spiedigitallibrary.org/conference-proceedings-of-spie on 26 Apr 2023 Terms of Use: https://www.spiedigitallibrary.org/terms-of-use 


\section{Conference Committee}

Symposium Chairs

Steven C. Horii, The University of Pennsylvania Health System

(United States)

Berkman Sahiner, U.S. Food and Drug Administration (United States)

Conference Chairs

Neb Duric, Delphinus Medical Technologies, Inc. (United States) and Karmanos Cancer Institute (United States)

Brecht Heyde, KU Leuven (Belgium) and Duke University

(United States)

Conference Program Committee

Mark A. Anastasio, Washington University in St. Louis (United States)

Jeffrey C. Bamber, The Royal Marsden NHS Foundation Trust (United Kingdom)

Johan G. Bosch, Erasmus Universiteit Rotterdam (Netherlands)

Jan D'hooge, KU Leuven (Belgium)

Marvin M. Doyley, University of Rochester (United States)

Stanislav Y. Emelianov, The University of Texas at Austin (United States)

Mostafa Fatemi, Mayo Clinic College of Medicine (United States)

Aaron Fenster, Western University (Canada)

Jérémie Fromageau, The Institute of Cancer Research

(United Kingdom)

James F. Greenleaf, Mayo Clinic (United States)

Emma J. Harris, The Institute of Cancer Research (United Kingdom)

Martin Christian Hemmsen, Technical University of Denmark

(Denmark)

Michael Jaeger, Universität Bern (Switzerland)

Jørgen Arendt Jensen, Technical University of Denmark (Denmark)

David H. Kim, Analogic Corporation (United States)

Roman G. Maev, University of Windsor (Canada)

Stephen A. McAleavey, University of Rochester (United States)

Mohammad Mehrmohammadi, Wayne State University

(United States)

Serge Mensah, Aix-Marseille Université (France)

Svetoslav I. Nikolov, BK Ultrasound (Denmark)

Olivier Roy, Karmanos Cancer Institute (United States)

Nicole V. Ruiter, Karlsruher Institut für Technologie (Germany) 
Kai E. Thomenius, Massachusetts Institute of Technology

(United States)

William F. Walker, University of Virginia (United States)

Session Chairs

1 Motion and Deformation Imaging

Brett C. Byram, Vanderbilt University (United States)

2 Ultrasound Tomography and Reconstruction

Olivier Roy, Delphinus Medical Technologies, Inc. (United States) and Karmanos Cancer Institute (United States)

Torsten Hopp, Karlsruher Institut für Technologie (Germany)

3 Ultrasound Image Analysis and Tissue Characterization

Brecht Heyde, KU Leuven (Belgium) and Duke University (United States)

4 Ultrasound Image Guidance: Joint Session with Conferences 9786

and 9790

Parvin Mousavi, Queen's University (Canada)

Brecht Heyde, KU Leuven (Belgium) and Duke University (United States)

5 Novel Imaging Strategies and Signal Processing

Mohammad Mehrmohammadi, Wayne State University

(United States)

6 Keynote and New Applications of Ultrasound in Medicine and

Biology

Brian W. Anthony, Massachusetts Institute of Technology

(United States)

Neb Duric, Delphinus Medical Technologies, Inc. (United States) and Karmanos Cancer Institute (United States)

7 Transducers and Beamforming

Jørgen Arendt Jensen, Technical University of Denmark (Denmark)

Marko Jakovljevic, Duke University School of Medicine (United States) and Stanford University (United States) 


\section{Medical Imaging Award Recipients}

\section{Robert F. Wagner Best Student Paper Award}

Robert F. Wagner was an active scientist in the SPIE Medical Imaging meeting, starting with the first meeting in 1972 and continuing throughout his career. He ensured that the $\mathrm{BRH}$, and subsequently the $\mathrm{CDRH}$, was a sponsor for the early and subsequent Medical Imaging meetings, helping to launch and ensure the historical success of the meeting. The Robert $F$. Wagner All-Conference Best Student Paper Award (established 2014) is acknowledgment of his many important contributions to the Medical Imaging meeting and his many important advances to the field of medical imaging.

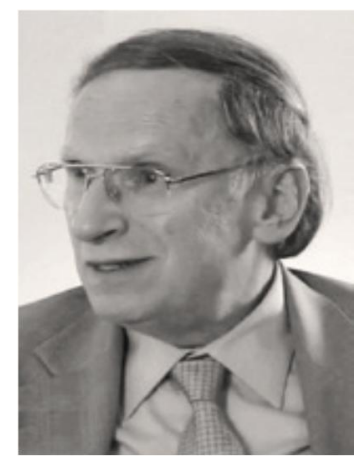

This award is cosponsored by:

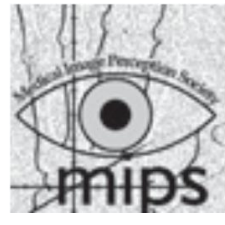

The Medical Image Perception Society

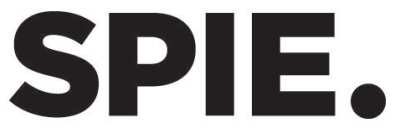

\section{Recipients:}

First Place: MIND Demons for MR-to-CT deformable image registration in image-guided spine surgery (9786-16)

S. Reaungamornrat, T. De Silva, A. Uneri, Johns Hopkins Univ. (United States), J.-P. Wolinsky, Johns Hopkins Hospital (United States), A. J. Khanna, Johns Hopkins Health Care \& Surgery Ctr. (United States), G. Kleinszig, S. Vogt, Siemens Healthcare (Germany), J. L. Prince, J. H. Siewerdsen, Johns Hopkins Univ. (United States)

Second Place: Design, fabrication, and implementation of voxel-based 3D printed textured phantoms for task-based image quality assessment in CT (9783-76)

Justin Solomon, Duke Univ. School of Medicine (United States), Alexandre Ba, Institut Univ. de Radiophysique Appliquée (Switzerland), Andrew Diao, Duke Univ. (United States), Joseph Lo, Elianna Bier, Duke Univ. School of Medicine (United States), François Bochud, Institut Univ. de Radiophysique Appliquée (Switzerland), Michael Gehm, Duke Univ. (United States), Ehsan Samei, Duke Univ. School of Medicine (United States)

\section{Conference 9790 Awards}

\section{Cum Laude Poster Award}

First Place: Endocavity ultrasound, fiber-guided photoacoustic, and quasi-static elasticity imaging (9790-59)

Yan Yan, Sirisha Kondle, Vishal N. Srivastava, Bhargava Saripalli, Jinjun Xia, Edgar A. Hernandez, Mohammad Mehrmohammadi, Wayne State Univ. (United States) 
Proc. of SPIE Vol. $9790979001-14$

Downloaded From: https://www.spiedigitallibrary.org/conference-proceedings-of-spie on 26 Apr 2023 Terms of Use: https://www.spiedigitallibrary.org/terms-of-use 